\title{
An Experimental Study on Hybrid Noncompression CF Bracing and GF Sheet Wrapping Reinforcement Method to Restore Damaged RC Structures
}

\author{
Kang Seok Lee \\ School of Architecture, Chonnam National University, Gwangju 500-757, Republic of Korea \\ Correspondence should be addressed to Kang Seok Lee; kslnist@jnu.ac.kr
}

Received 22 May 2015; Accepted 18 August 2015

Academic Editor: Ivo Caliò

Copyright @ 2015 Kang Seok Lee. This is an open access article distributed under the Creative Commons Attribution License, which permits unrestricted use, distribution, and reproduction in any medium, provided the original work is properly cited.

\begin{abstract}
We describe a novel technique for restoration of reinforced concrete (RC) structures that have sustained damage during an earthquake. The reinforcement scheme described here is a hybrid seismic retrofitting technique that combines noncompression X-bracing using CF with externally bonded GF sheets to strengthen RC structures that have sustained damage following an earthquake. The GF sheet is used to improve the ductility of columns, and the noncompression CF X-bracing system, which consists of CF bracing and anchors to replace the conventional steel bracing and bolt connections, is used to increase the lateral strength of the framing system. We report seismic restoration capacity, which enables reuse of the damaged RC frames via the hybrid CF $\mathrm{X}$-bracing and GF sheet wrapping system. Cyclic loading tests were carried out to investigate hysteresis of the lateral load-drift relations, as well as the ductility. The GF sheet significantly improved the ductility of columns, resulting in a change in failure mode. The strengthening effect of conventional CF sheets used in columns is not sufficient with respect to lateral strength and stiffness. However, this study results in a significant increase in the strength of the structure due to the use of CF X-bracing and inhibited buckling failure of the bracing. This result can be exploited to develop guidelines for the application of the reinforcement system to restore damaged RC structures.
\end{abstract}

\section{Introduction}

To restore an earthquake-damaged community as rapidly as possible, a well-prepared reconstruction strategy is essential, as was revealed by the 1995 Kobe Earthquake in Japan, the 1999 Chi-Chi Earthquake in Taiwan, the 2008 Sichuan Earthquake in China, the 2010 Chile Earthquake, the 2011 Christchurch Earthquake in New Zealand, the 2012 Great East Japan Earthquake, and the 2013 Lushan Earthquake in China. When an earthquake strikes a community and damage to buildings occurs, inspection of this damage is urgently required to identify which buildings are safe and which are prone to damage due to aftershocks. The residual seismic capacity of the damaged buildings should then be quantitatively evaluated, and technically and economically sound solutions should be identified (i.e., effective reinforcement) to restore the damaged buildings.

Seismic retrofit techniques of damaged buildings has received relatively little interest, however, and most research, including guidelines and standards, has focused on seismic evaluation and retrofit of existing buildings (e.g., the Handbook for Seismic Evaluation of Buildings: A Prestandard [1], Prestandard and Commentary for Seismic Rehabilitation of Buildings [2], Standard for Seismic Evaluation of Existing Reinforced Concrete Buildings and Guidelines for Seismic Retrofit of Existing Reinforced Concrete Buildings, and the Technical Manual for Seismic Evaluation and Seismic Retrofit of Existing Reinforced Concrete Buildings [3]). Research into restoration of damaged buildings is lacking, especially seismic retrofitting techniques for buildings that have sustained damage following an earthquake.

Aschheim and Black [4] reported a nonlinear dynamic analysis whereby serial continuous earthquake loading, including the main shock and aftershocks, resulted in cumulative damage to the structural system. Lee and Foutch [5] reported an analytical method for reliability-based seismic performance evaluation of buildings damaged by earthquakes. Li and Ellingwood [6] showed that the additional 
degree of damage to structures due to aftershocks was strongly related to the earthquake damage caused by main shock, that is, residual deformation.

Maeda et al. [7] proposed a technique for postearthquake damage evaluation of reinforced concrete (RC) buildings based on the residual seismic capacity, which is defined as the ratio of the postearthquake seismic capacity to the initial capacity. This enabled rapid restoration to prevent damage during aftershocks and provided permanent restoration. The residual seismic capacity was calculated based on the seismic capacity reduction factor, which was determined using cyclic loading tests and nonlinear dynamic analyses, and was applied to the 2004 Niigata Earthquake and the 2012 Great East Japan Earthquake.

Most existing research into buildings damaged by earthquakes has focused on methods of seismic capacity evaluation of the damaged structures following the main shock. Seismic retrofitting techniques for permanent restoration of the damaged buildings, however, have received relatively little attention. Effective reinforcement techniques for restoring the damaged buildings are also attractive from an economic point of view.

Recently, fiber-reinforced polymer (FRP) sheets using carbon fiber (CF) or glass fiber (GF) have been widely applied to reinforcement of existing structures and are frequently used to restore columns that have been damaged by earthquakes. Strengthening methods using FRP sheeting have been shown to significantly increase the ductility of existing columns; however, the increase in lateral strength and stiffness is typically not sufficient, and interstory drift of buildings cannot be easily controlled [8].

The most efficient reinforcement methods for increasing resistance to lateral loading during earthquakes is steel bracing, which can result in a significant increase in the load-resistance of earthquake-damaged RC structures [9]. In particular, Viswanath et al. [10] analytically showed that cross bracing (X-bracing) significantly increased the structural stiffness and decreased interstory drift. X-bracing systems have been applied to five-story RC buildings, which when originally built did take earthquake resistance into account, and significantly enhanced the strength of these structures [11]. Scale tests for seven-story RC buildings reinforced using steel X-bracing have also been carried out, and the results indicate enhanced vertical and horizontal resistance, until buckling failure of the bracing occurred in response to the earthquake loading [12]. An RC school building was retrofitted using posttensioned rod braces, which resulted in an increased moment capacity, rather than increased ductility [13]. Research has shown that direct connections between the concrete structure and the bracings result in superior structural properties in terms of earthquake resistance [9, 14-17].

$\mathrm{X}$-bracing significantly increases the structural stiffness and strength of structures; however, it has also been shown that conventional steel $\mathrm{X}$-bracing methods typically result in brittle failure at the connections between the braces and the building or buckling failure of the braces. There have been many attempts to eliminate buckling failure in the braces, which have mainly focused on the use of bucklingrestrained brace (BRB) systems. One report of calculations of a confidence parameter of buckling failure in a four-story steel office building highlighted the importance of carefully assessing the braced steel frames, especially to prevent total collapse of the building [18].

In Japan, BRB frames have become increasingly popular, due to their excellent earthquake resistance [19]. In 2009, a new type of bidirectional-resistant ductile end diaphragm using BRBs was introduced for bridges [20]. BRB devices cased with steel tubes and mortar have been investigated, and the results indicate that it is possible to acquire reasonably efficient and economical performance during cyclic loading [21]. The configurations of X-braced systems have been investigated to obtain performance that economically mitigates residual drift, limits soft story formation, and prevents undesirable failure modes at the beam-column connections. A buckling-restrained braced frame (BRBF) with pinned and moment connections has been proposed, and the efficiency of the structure was evaluated using nonlinear dynamic analysis [22]. A nine-story building reinforced using a special concentrically braced frame (SCBF), a buckling-restrained bracing frame (BRBF), and a mega-bracing frame (MBF) was simulated to evaluate the seismic resistance. The MBF configuration was found to be the most resistant to lateral drift, even though it was relatively lightweight [23]. Tamai and Takamatsu [24] also reported innovative methods to prevent buckling failure using noncompression bracing featuring sliding brace connections.

Carbon fiber (CF) X-bracing uses carbon fiber bracing and anchors rather than conventional steel bracing and bolt connections. Externally bonded carbon fiber anchors have been developed and tested to evaluate the efficiency of anchorage, force continuity, and force transfer. The results indicate that it is possible to achieve shear strengthening, flexural enhancement, confinement, and blast hardening [25]. Other researchers used pull-out [26, 27] and shear [28] methods to evaluate the composite structures and found CF bracing to be a practical engineering solution for reinforcing RC structures.

In this paper we report a hybrid seismic retrofit methodology combined with a noncompression X-bracing system using CF and externally bonded GF sheeting for reinforcing $\mathrm{RC}$ structures that have sustained damage following an earthquake. GF sheeting was used to improve the ductility of damaged columns. The noncompression CF X-bracing system, which consists of $\mathrm{CF}$ bracing and anchors rather than conventional steel bracing and bolt connections, was used to increase the lateral strength of the framing system. Seismic restoration of damaged RC frames reinforced using this hybrid system was investigated using cyclic loading tests, and the stiffness and ductility of the structure, the failure modes, and hysteresis of the lateral load-drift response were assessed.

\section{Hybrid Methodology Using CF X-Bracing and GF Sheet Wrapping}

The hybrid seismic retrofitting methodology described here uses a combination of noncompression CF X-bracing and externally bonded GF sheeting to reinforce damaged RC structures, as shown in Figure 1. The hybrid system consists 

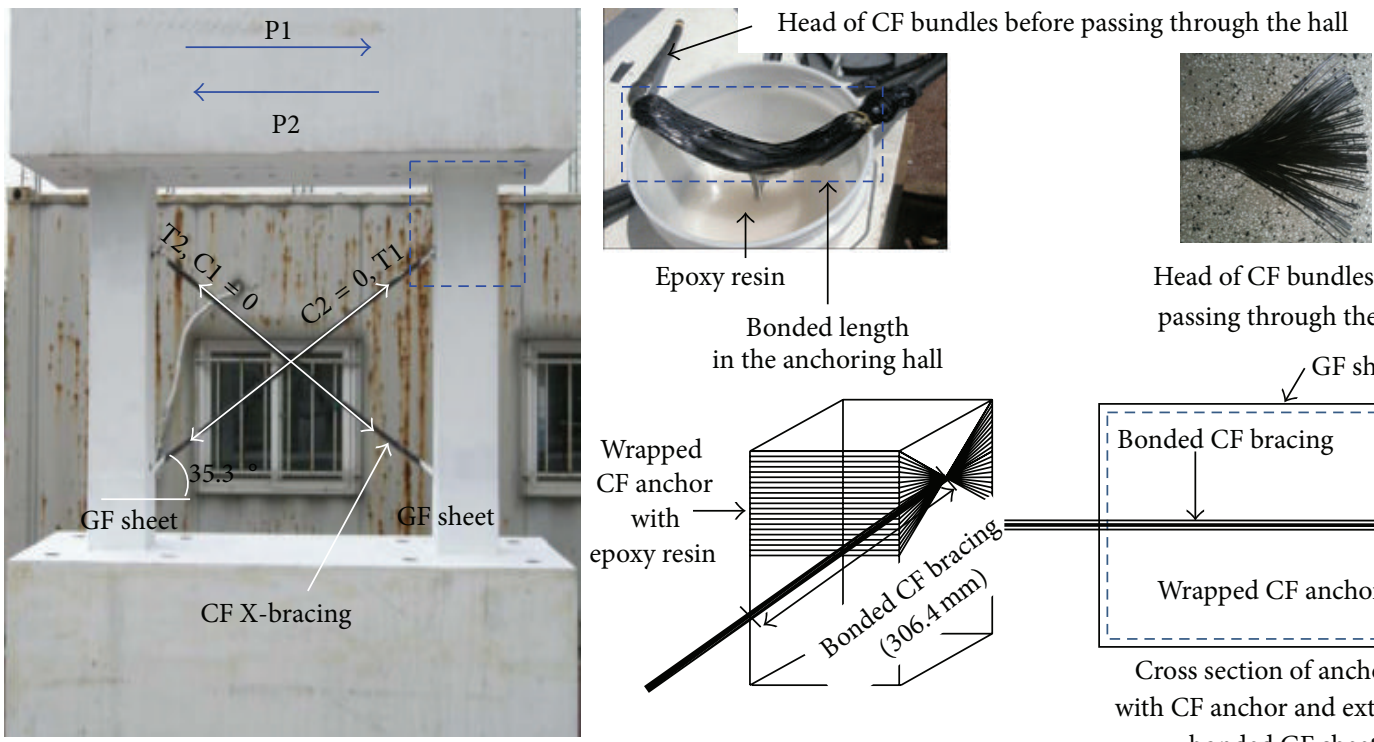

Epoxy resin

Bonded length in the anchoring hall

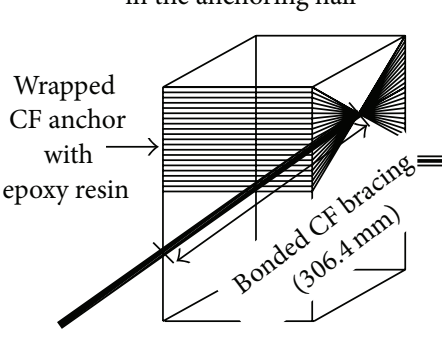

Head of CF bundles after passing through the hall

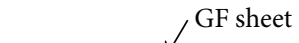

FIGURE 1: A schematic diagram showing the hybrid CF X-bracing and GF sheet wrapping system.

of CF braces, a CF anchor, and GF sheeting. Following the formation of anchor holes in the damaged column, epoxy-impregnated CF composite bracings were installed through the anchor holes at both edges of the column. $\mathrm{CF}$ bundles at the end of the CF X-bracing surround the column edge to form the anchors. This fiber anchoring system has been shown not to exhibit fiber fracture, and concrete failure occurred following the application of shear loads that were approximately twice those that led to failure in specimens without the fiber anchors [29]. The GF sheeting was externally bonded to increase the ductility of the damaged columns, including the CF anchor points.

Consequently, it is possible to prevent premature debonding failure at the anchor points by using three anchorage points: the support is bonded at the anchor hole, the CF anchor, and is externally bonded to the GF sheeting. The structural behavior of the hybrid CF X-bracing and GF sheet wrapping system is illustrated in Figure 1. When a lateral force is applied, as shown by $\mathrm{P} 1$, the ascending brace experiences a tensile force $\mathrm{T} 1$, and the descending brace does not experience a compressive force: that is, $\mathrm{C} 1=0$. When a lateral force is applied in the opposite direction, shown by P2, the descending brace has a tensile force $\mathrm{T} 2$ and the ascending brace also has no compressive force, so that $\mathrm{C} 2=0$. Therefore, there are no compressive stresses on the CF X-bracing in response to lateral loads.

\section{Test Specimens}

3.1. Material Characteristic of CF for X-Bracing and GF Composite for Wrapping. Two different CF X-bracings were used in this study: one fabricated from carbon fiber yarn provided by Fyfe, USA (type-A), and one fabricated by Toray, Japan (type-B). Table 1 lists details of these fibers; type-A fiber had a tensile strength of $3,790 \mathrm{MPa}$ and a diameter of $15.5 \mathrm{~mm}$, and type-B fiber had a tensile strength of 4,900 MPa and a diameter of $15.8 \mathrm{~mm}$. The mechanical strength was experimentally characterized according to the KS K 0412 Korean Standard to measure the tensile strength and elongation of the filament. Failure occurred at approximately half of the manufacturer's listed tensile strength; however, this measurement depends critically on the anchorage and angle of the filaments. During the design process, a safety margin of the tensile strength of the CF anchor was considered based on the results of these tensile tests.

Table 2 lists the material properties of the GF composite used in this study. The GF was produced by Conclinic (CAFGL1000) [30] in Korea and had a tensile strength at failure of $500 \mathrm{MPa}$ and an elastic modulus of 25,000 MPa.

3.2. Material Properties of Steel Rebar, Concrete, and Epoxy Resin. The listed compressive strength of the concrete was $f_{c}=30 \mathrm{MPa}$, and cylindrical compression tests resulted in a figure of $31.8 \pm 1.0 \mathrm{MPa}$. The tensile strength of the steel reinforcing bar (rebar) was $400 \mathrm{MPa}$. Two different diameter rebars were used: D10 for the stirrup and D22 for the main rebar of specimens (see Section 3.3 for further details). The uniform building code [31] pertains to RC design in earthquake zones and specifies that the ratio of the tensile stress to the yield stress of the rebar should not be less than 1.25 , to ensure adequate ductility under simulated earthquake loading. In our tensile testing of the rebar, this ratio was 1.45 for the D10 rebar and 1.35 for the D22 rebar. The tensile strength of the steel rebar was measured using a universal testing machine (UTM); we find $518.3 \pm 1.15 \mathrm{MPa}$ for the D10 rebar and $538.0 \pm 12.17 \mathrm{MPa}$ for the D22 rebar, where the error margins correspond to the standard deviation of the measurement results.

The anchoring method used epoxy resin as an adhesive for the CF anchors and externally bonded glass fiber sheeting. Table 3 lists the material properties of the epoxy resin used in this study. 
TABLE 1: The physical properties of the carbon fibers used in this study.

\begin{tabular}{|c|c|c|c|c|c|c|c|c|}
\hline Classification & $\begin{array}{c}\text { Yarn } \\
\text { number }\end{array}$ & $\begin{array}{c}\text { Tensile } \\
\text { strength }(\mathrm{MPa})\end{array}$ & $\begin{array}{l}\text { Mass per unit } \\
\text { length }(\mathrm{g} / \mathrm{km}) \\
\quad(\mathrm{tex})\end{array}$ & $\begin{array}{l}\text { Density } \\
\left(\mathrm{g} / \mathrm{cm}^{3}\right)\end{array}$ & $\begin{array}{c}\text { Filament } \\
\text { diameter }(\mathrm{cm})\end{array}$ & $\begin{array}{l}\text { Sectional area } \\
\left(\mathrm{cm}^{2}\right)\end{array}$ & $\begin{array}{c}\text { Brace } \\
\text { diameter } \\
(\mathrm{mm})\end{array}$ & $\begin{array}{l}\text { Tensile force } \\
\qquad(\mathrm{kN})\end{array}$ \\
\hline Type-A & $100^{*}$ & 3,790 & 3,273 & 1.74 & 0.155 & 1.881 & 15.5 & $\begin{array}{c}712.9 \\
(310.1)^{* *}\end{array}$ \\
\hline Type-B & $200^{*}$ & 4,900 & 1,761 & 1.80 & 0.112 & 1.957 & 15.8 & $\begin{array}{c}958.8 \\
(454.4)^{* *}\end{array}$ \\
\hline
\end{tabular}

* The yarn number data are based on manufacturers' specifications (type-A: Fyfe, USA, and type-B: Toray, Japan). The CF X-bracing was fabricated in-house.

** Parentheses indicate the material test results from the institute in Korea.

TABle 2: Physical properties of the glass fiber composite used in this study.

\begin{tabular}{lccc}
\hline Classification & $\begin{array}{c}\text { Designed tensile } \\
\text { strength at failure } \\
(\mathrm{MPa})\end{array}$ & $\begin{array}{c}\text { Elastic modulus for } \\
\text { tensile }(\mathrm{MPa})\end{array}$ & $\begin{array}{c}\text { Tensile strain at } \\
\text { failure }(\%)\end{array}$ \\
\hline $\begin{array}{l}\text { GFRP composite } \\
\text { (Conclinic, Korea) }\end{array}$ & 500 & 25,000 & 2.3 \\
\hline
\end{tabular}

TABLE 3: The material properties of the epoxy resin used in this study.

\begin{tabular}{lcccc}
\hline Classification & $\begin{array}{c}\text { Compressive } \\
\text { strength }(\mathrm{MPa})\end{array}$ & $\begin{array}{c}\text { Flexural strength } \\
(\mathrm{MPa})\end{array}$ & $\begin{array}{c}\text { Tensile elastic } \\
\text { modulus }(\mathrm{MPa})\end{array}$ & Density $\left(\mathrm{g} / \mathrm{cm}^{3}\right)$ \\
\hline Epoxy resin & 89.8 & 81.6 & 2857.1 & 1.16 \\
\hline
\end{tabular}

3.3. Specimen Design and Test Variables. Shear failure control specimens were designed and fabricated for experimental tests. Figure 2 shows details of the shear failure (SF) series of control specimens. The purpose of these tests was to investigate the structural performance of damaged RC columns, which had reduced shear strength, with the hybrid CF Xbracing and GF sheet wrapping reinforcement system. The specimens were designed according to the guidelines for the load-carrying capacity specified by the Japan Building Disaster Prevention Association [3].

A total of three specimens were considered for the shear failure mode, including the two types of CF X-bracing and GF sheet wrapping systems. The average vertical load on both columns was approximately $3 \mathrm{MPa}$, which is $10 \%$ of the nominal compressive strength of the concrete. The ratio of the column clear height, $h_{0}$, to the depth, $D$, was $h_{0} / D=$ 6.0. The concrete stub member was installed at the top of the specimen to confine the columns. Table 4 lists the loadcarrying capacity calculated according to JBDPA [3].

3.4. Fabrication of Test Specimens Structurally Restored by the Hybrid Strengthening System. To experimentally investigate the seismic resistance of the structurally restored RC structures, a series of control specimens, SF-0, were designed to exhibit shear failure. The reinforcement ratio of the SF series was designed so that the structures would exhibit shear failure modes. Two specimens were fabricated, as shown in Figure 2. Each specimen was then tested until class-V damage occurred, as shown in Figure 3, and defined in Table 5 [7, 32]. The tests were carried out based on a cyclic loading scheme, which will be described later (see Table 7). Following completion of the cyclic loading to simulate earthquake damage, the damaged structures were reinforced using the hybrid CF X-bracing with either type-A or type-B CF and with GF sheet wrapping. There were, therefore, three types of specimen, which were investigated using cyclic loading experiments. All specimens had identical dimensions, and a stub with a high stiffness was installed at the top of each specimen to provide confinement of the columns. Table 6 lists details of the test specimens.

Figure 4 shows details of the fabrication of the specimens. Following completion of the specimens (SF-R1 and SF$\mathrm{R} 2$ ), which sustained class-V damage, these were treated by injecting epoxy resin into the cracks. Anchor holes were then drilled at the edges of the top and bottom of each column. The anchor holes were drilled to pass through the CF bracing using a CF anchor. Inclined holes were formed, allowing the CF bracing to pass, as shown in Figure 4(b). The CF Xbracings were passed through the anchor holes and stretched tight. The anchor points were reinforced by bonding the CF anchors using epoxy resin. Externally bonded glass fiber was then applied to the entirety of the column.

To enhance the bonding, the surfaces were treated using a priming process. The GF sheet wrapping was applied to the damaged RC columns with two orientations: longitudinal for strengthening of the main reinforcements and horizontal for lateral reinforcement to enhance the seismic resistance. The GF sheeting was cured for three days for each orientation. Figure 5 shows details of the control specimen (SF-0) and the specimens strengthened using the hybrid CF-X bracing and GF sheet wrapping 15 system (SF-R1 and SF-R2).

3.5. Test Procedures. The main purpose of the tests was to investigate the seismic restoration capacity for reuse of the damaged RC frame reinforced using the hybrid CF Xbracing and GF sheet wrapping system. We investigated the 

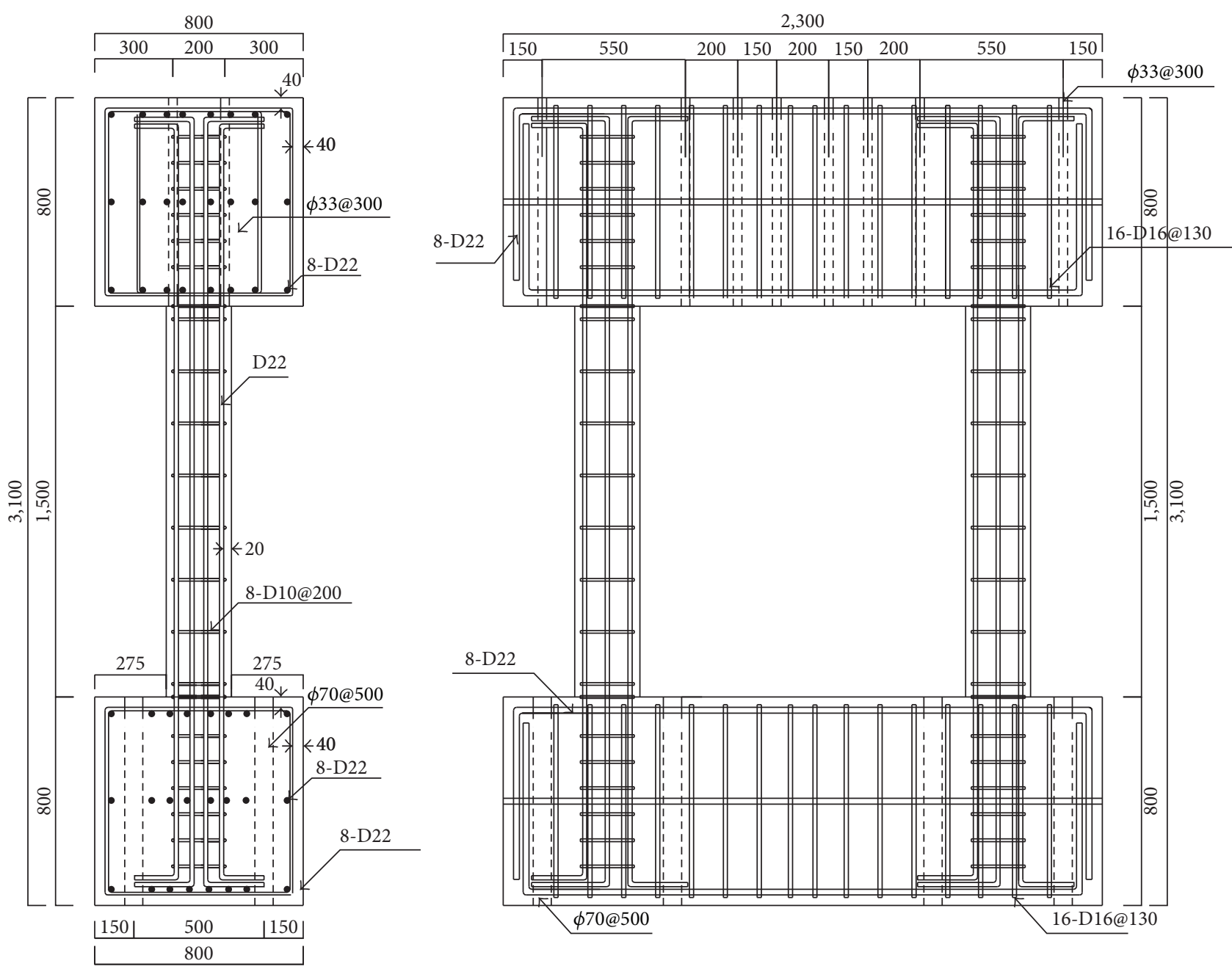

FIGURE 2: Details of the SF-series of control specimens (dimensions are in $\mathrm{mm}$ ).

TABLE 4: The load-carrying capacity of the columns calculated according to JBDPA [3].

\begin{tabular}{|c|c|c|c|c|c|}
\hline Specimens & $\begin{array}{l}\text { Axial force } \\
\quad N(\mathrm{kN})\end{array}$ & $\begin{array}{l}\text { Ultimate flexural } \\
\text { strength } \\
M_{u}(\mathrm{kN} \cdot \mathrm{m})\end{array}$ & $\begin{array}{c}\text { Shear force at the point } \\
\text { of ultimate flexural } \\
\text { failure } \\
V_{m u}(\mathrm{kN})\end{array}$ & $\begin{array}{l}\text { Ultimate shear } \\
\text { strength } \\
V_{s u}(\mathrm{kN})\end{array}$ & $\begin{array}{c}\text { Ultimate lateral } \\
\text { load-carrying capacity } \\
V_{u}(\mathrm{kN})\end{array}$ \\
\hline SF-0 & 187.5 & 144.9 & 193.2 & 110.8 & $110.8(221.6)^{*}$ \\
\hline
\end{tabular}

${ }^{*}$ The ultimate lateral load-carrying capacities of the two columns are shown in parentheses.

stiffness and ductility of the structure, the failure modes, and hysteresis of the lateral load-drift relations. The two columns were subjected to a constant vertical load of $187.5 \mathrm{kN}$ using two $1,000 \mathrm{kN}$ actuators. A 2,000 $\mathrm{kN}$ actuator was used to apply the lateral load. Figure 6 shows the experimental configuration. A cyclic loading scheme with a predetermined displacement was used. The load cycles were designed to have antisymmetric moments in the lateral direction. Each loading step consisted of three cycles. Table 7 lists the load cycles that were applied to the test specimens.

\section{Failure Patterns and Load-Displacement Relations}

For the specimens reinforced using the hybrid system described here, the compressive behavior of the $\mathrm{CF} \mathrm{X}$ bracing was out-of-plane. This was originally expected to be compression-free, so that buckling failure of the braces could not occur. The failure of modes and hysteresis characteristics of the control (SF-0) and reinforced specimens (SF-R1 and SF-R2) differed significantly. All of the SF-R series failed in 
TABle 5: Definition of damage classes [7, 32].

\begin{tabular}{ll}
\hline $\begin{array}{l}\text { Damage } \\
\text { class }\end{array}$ & $\begin{array}{l}\text { Description of damage } \\
\text { I }\end{array}$ \\
II & $\begin{array}{l}\text { Visible narrow cracks on concrete surfaces. Cracks } \\
\text { are less than } 0.2 \mathrm{~mm} \text { wide }\end{array}$ \\
& $\begin{array}{l}\text { Visible cracks on concrete surface. The crack widths } \\
\text { are in the range } 0.2-1 \mathrm{~mm}\end{array}$ \\
LiI & $\begin{array}{l}\text { Localized crushing of the concrete cover. Noticeable } \\
\text { wide cracks. The crack widths are in the range }\end{array}$ \\
& $\begin{array}{l}\text { 1-2 mm } \\
\text { Crushing of concrete with exposed rebar. Spalling of } \\
\text { cover concrete. The cracks' widths are more than }\end{array}$ \\
IV & $\begin{array}{l}2 \text { mm wide } \\
\text { Buckling of rebar. Cracks in the core concrete. } \\
\text { Visible vertical deformation of the columns, walls, or } \\
\text { both. Visible settlement or inclination of the } \\
\text { building, or both }\end{array}$ \\
V &
\end{tabular}

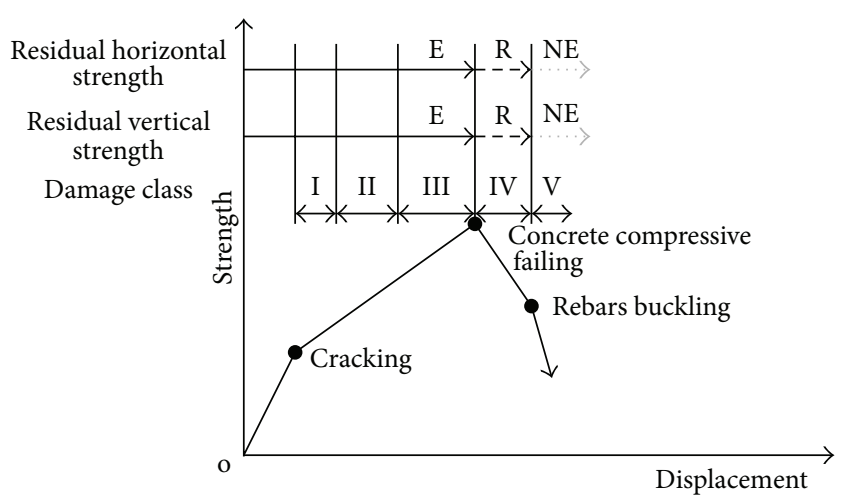

E: existence
R: reduction
NE: nonexistence

FIGURE 3: Relationship between degree of damage and load displacement of the shear member [32].

response to flexural strain with a large energy dissipation capacity, whereas the control SF-0 specimens exhibited shear failure, which is consistent with the design of the structure.

In the following discussion, we focus on the crack and failure patterns in terms of the lateral displacement and loaddisplacement relations during the final stages of the test. Each loading step was identical during the three loading cycles. Table 8 lists the results of mechanical characterizations in terms of shear strength and displacement with positive and negative loads for the three specimens. The yield strength and displacement of the specimens were described using Park's definition, which is the most realistic definition available for the yield displacement for RC structures [33]. The yield displacement of the equivalent elastoplastic system with a reduced stiffness is given by the secant stiffness at $75 \%$ of the ultimate lateral load of the system.

4.1. Control Specimen. The control specimen (SF-0) was designed so that it would exhibit shear failure and was tested until class-V damage occurred in order to simulate earthquake damage (see Figure 3). Figure 7 shows the crack patterns that were observed on the SF-0 specimen following the final stages of the cyclic load tests, and Figure 8 shows the load-displacement curve.

During the 15th loading cycle (5th loading step, $R=$ $1 / 200$ ), with a load of $-166 \mathrm{kN}$, slight flexural cracks appeared at the lower end of the right column, and shear cracks were observed at the upper end of the column. No cracking occurred in the middle of the column. When the applied load reached $224 \mathrm{kN}$, at the 21st negative loading cycle (7th loading step, $R=1 / 120$ ), more shear cracks appeared, with increased width. A notable difference was the observation of peeling of the concrete cover due to shear forces at the 27th loading cycle (9th loading step, $R=1 / 86$ ). This is likely to be the result of insufficient shear confinement. Shear failure occurred in both columns following the application of a negative load of $150 \mathrm{kN}$, with a lateral drift of $30.0 \mathrm{~mm}(R=1 / 50)$.

The maximum load capacity of the frame of the SF-0 specimen was $278 \mathrm{kN}$ at the 27 th negative loading cycle (9th loading step, $R=1 / 86$ ), with a lateral drift of $17.5 \mathrm{~mm}$ (see Table 8 and Figure 8 ). The maximum positive load capacity was $227 \mathrm{kN}$, with a lateral drift of $14.7 \mathrm{~mm}$, and exhibited slightly lower strength in response to positive loads than negative loads.

4.2. Hybrid CF X-Bracing and GF Sheet Wrapping Reinforced Specimen SF-R1. Figure 9 shows a photograph of the SFR1 specimen following the cyclic loading test, and Figure 10 shows the load-displacement curves. The SF-R1 specimen featured the hybrid CF X-bracing with type-A carbon fiber and GF sheet wrapping. The specimen was reinforced following sustaining class-V damage (see Figures 3 and 5). The SF-R1 specimen did not exhibit surface cracks, because the surface was coated with externally bonded GF sheeting.

Following the 42nd negative loading cycle (14th loading step, $R=1 / 38$ ), with a load of $-464 \mathrm{kN}$, the strength capacity did not increase, and a maximum load was reached. When the applied load reached the 58th cycle $(R=1 / 13)$, the specimen exhibited failure at both ends of the RC column, and buckling failure of the CF X-braces did not occur.

As shown in Figure 10, the maximum load capacity of the frame of the SF-R1 specimen was a negative load of $464 \mathrm{kN}$, with a lateral drift of $44 \mathrm{~mm}$ (see also Table 8). The maximum positive load capacity was $453 \mathrm{kN}$ with a lateral drift of $44.8 \mathrm{~mm}$, which is similar to the maximum negative load capacity. Note that the hybrid reinforced SF-R1 specimen exhibited a significant increase in the ductility of the columns, resulting in a change in the failure mode, as well as an increase in the strength capacity, compared with the SF-0 control specimen (see Figure 8).

4.3. Hybrid CF X-Bracing and GF Sheet Wrapping Reinforced Specimen SF-R2. The SF-R2 specimen was strengthened using the hybrid CF X-bracing with type-B carbon fiber and GF sheet wrapping. Surface cracks were not observed because of the externally bonded GF sheeting, as with the SF-R1 specimen.

Figure 11 shows a photograph of the SF-R2 specimen following the cyclic loading tests, and Figure 12 shows the 
TABLE 6: Summary of the specimens used in this study.

\begin{tabular}{|c|c|c|c|c|c|c|c|c|}
\hline \multirow[b]{2}{*}{ Specimens } & \multirow{2}{*}{$\begin{array}{c}\text { Column clear } \\
\text { height } \\
h_{0}(\mathrm{~mm})\end{array}$} & \multirow{2}{*}{$\begin{array}{l}\text { Column depth } \\
\quad D(\mathrm{~mm})\end{array}$} & \multirow[b]{2}{*}{$h_{0} / D$} & \multirow{2}{*}{$\begin{array}{c}\text { Tensile reinforcement } \\
\text { ratio } \\
\rho_{f}(\%) \\
\end{array}$} & \multirow{2}{*}{$\begin{array}{c}\text { Shear reinforcement } \\
\text { ratio } \\
\rho_{s}(\%) \\
\end{array}$} & \multicolumn{2}{|c|}{ Strengthening } & \multirow{2}{*}{$\begin{array}{c}\text { Repair of } \\
\text { crack }\end{array}$} \\
\hline & & & & & & $\begin{array}{c}\mathrm{CF} \\
\text { anchor }\end{array}$ & $\begin{array}{c}\text { GF } \\
\text { sheet }\end{array}$ & \\
\hline $\begin{array}{l}\text { SF-0 } \\
\text { (control) }\end{array}$ & 1500 & 250 & 6 & 2.48 & 0.29 & N/A & N/A & N/A \\
\hline SF-R1* & 1500 & 250 & 6 & 2.48 & 0.29 & Type-A & $\begin{array}{l}\text { GFRP } \\
2 \text { layers } \\
\text { per each } \\
\text { direction }\end{array}$ & $\begin{array}{c}\text { Epoxy } \\
\text { injection }\end{array}$ \\
\hline SF-R2* & 1500 & 250 & 6 & 2.48 & 0.29 & Type-B & $\begin{array}{c}\text { GFRP } \\
2 \text { layers } \\
\text { per each } \\
\text { direction }\end{array}$ & $\begin{array}{c}\text { Epoxy } \\
\text { injection }\end{array}$ \\
\hline
\end{tabular}

${ }^{*} \mathrm{R}$ : restoration strengthening.

TABLE 7: The load cycles used during the cyclic loading tests.

\begin{tabular}{lccc}
\hline Loading step & Loading cycles & $\begin{array}{c}\text { Drift angle } \\
R \text { (rad.) }\end{array}$ & $\begin{array}{c}\text { Lateral displacement } \\
\Delta(\mathrm{mm})\end{array}$ \\
\hline 1 & $1-3$ & $1 / 1000$ & 1.5 \\
2 & $4-6$ & $1 / 500$ & 3.0 \\
3 & $7-9$ & $1 / 333$ & 4.5 \\
4 & $10-12$ & $1 / 250$ & 6.0 \\
5 & $13-15$ & $1 / 200$ & 7.5 \\
6 & $16-18$ & $1 / 150$ & 10.0 \\
7 & $19-21$ & $1 / 120$ & 12.5 \\
8 & $22-24$ & $1 / 100$ & 15.0 \\
9 & $25-27$ & $1 / 85.7$ & 17.5 \\
10 & $28-30$ & $1 / 75$ & 20.0 \\
11 & $31-33$ & $1 / 60$ & 25.0 \\
12 & $34-36$ & $1 / 50$ & 30.0 \\
13 & $37-39$ & $1 / 43$ & 35.0 \\
14 & $40-42$ & $1 / 38$ & 40.0 \\
15 & $43-45$ & $1 / 30$ & 50.0 \\
16 & $46-48$ & $1 / 25$ & 60.0 \\
17 & $49-51$ & $1 / 21$ & 70.0 \\
18 & $52-54$ & $1 / 18$ & 85.0 \\
19 & $55-57$ & $1 / 14$ & 110.0 \\
20 & $58-60$ & $1 / 13$ & 120.0 \\
\hline
\end{tabular}

load-displacement curve. The lateral strength of the SF-R2 specimen did not increase at the 46th negative loading cycle (16th loading step, $R=1 / 25$ ) with a load of $-555 \mathrm{kN}$, which showed the maximum 16 load. At the 57th negative loading cycle $(R=1 / 14)$, the specimen reached the ultimate state. Similar to the SF-R1 specimen, failure occurred at both ends of the RC column, and buckling failure of the CF Xbraces did not occur. As shown in Figure 12, the maximum load capacity of the SF-R1 specimen was a negative load of $555 \mathrm{kN}$, with a lateral drift of $56.3 \mathrm{~mm}$ (see also Table 8). The maximum positive load capacity was $514 \mathrm{kN}$, with a lateral drift of $56.4 \mathrm{~mm}$.
As shown in Figure 12, the failure mode of the SFR2 specimen was flexural, whereas the control specimen exhibited the shear failure. The SF-R2 specimen also exhibited an increase in the strength capacity compared with SF-0. These results indicate that the hybrid CF X-bracing and GF sheet wrapping system is effective in increasing the energy dissipation capability of RC frames and can be used to restore damaged structures following an earthquake.

\section{Comparisons of Strength and Deformation Capacity}

Figure 13 shows envelop curves of the lateral load-displacement relations for the SF-0, SF-R1, and SF-R2 specimens. Table 9 lists the strength and deformation capacities, including the strength to ductility ratios. The larger of the maximum positive or negative loads were used. The ratio of the strength to the ductility is indicative of the reinforcement effect of the hybrid strengthened specimens (SF-R1 and SF-R2) in terms of the shear strength capacity compared with the control specimen (SF-0) and is expressed by the ratio of maximum load Vmax of the SF-R1 or SF-R2 specimens to that of the SF-0 specimen. The ductility ratio of the shear failure specimen (SF-0) is defined as the maximum displacement $\Delta_{\max }$ divided by yield displacement $\Delta_{y}$ : that is, $\mu_{s}=$ $\Delta_{\max } / \Delta_{y}$. The ductility ratio of the flexural failure specimens (SF-R1 and SF-R2) is defined as the ultimate displacement $\Delta_{u}$ divided by yield displacement $\Delta_{y}$ : that is, $\mu_{f}=\Delta_{u} / \Delta_{y}$. The yield strength and displacement of each specimen are listed in Table 9 and were defined based on Park's definition [33]; that is, the yield displacement of the equivalent elastoplastic system with a reduced stiffness is the secant stiffness at $75 \%$ of the ultimate lateral load of the system.

The maximum shear strength of the SF-R1 specimens reinforced using the hybrid CF X-bracing with type-A carbon fiber and GF sheet wrapping was $464 \mathrm{kN}\left(V_{y}=413 \mathrm{kN}\right)$ and that of the SF-R2 specimen braced using type-B carbon fiber was $555 \mathrm{kN}\left(V_{y}=515 \mathrm{kN}\right)$; this represents an increase of a factor of approximately 1.7-2.0, that is, $70-100 \%$ larger than the SF-0 control specimen (where the maximum shear strength was $278 \mathrm{kN}$ ). The ductility ratio of the SF- 0 specimen 


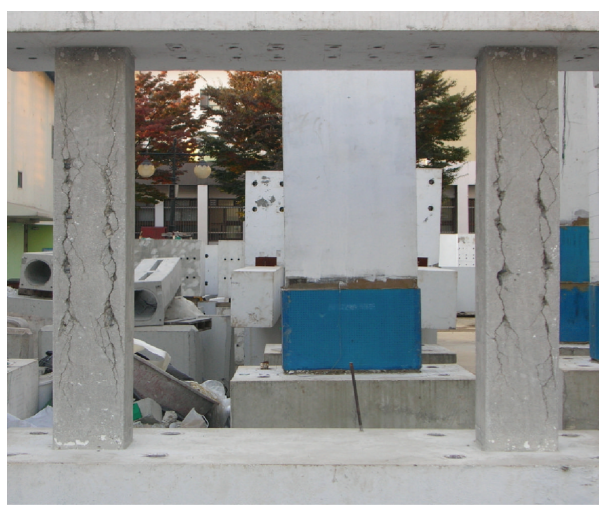

(a)

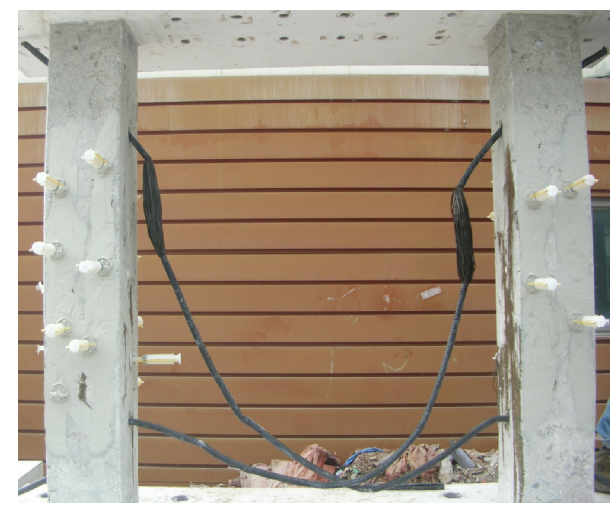

(c)

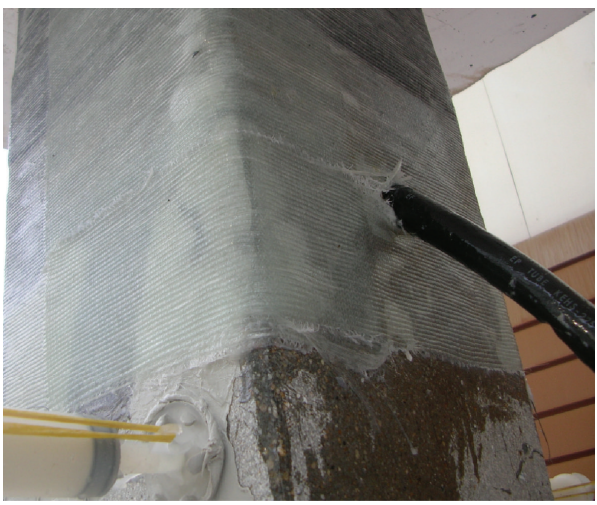

(e)

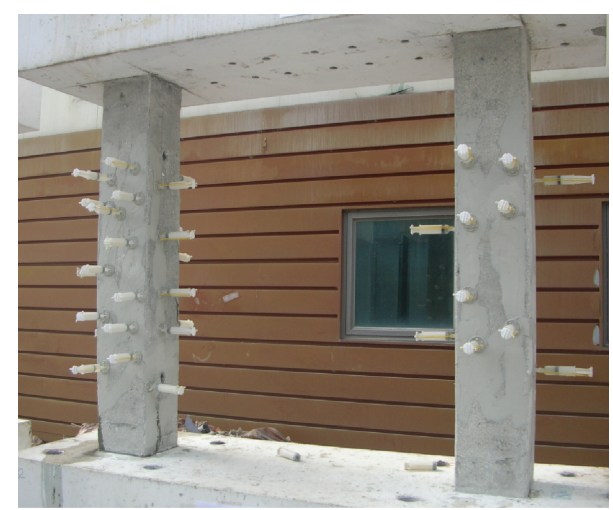

(b)

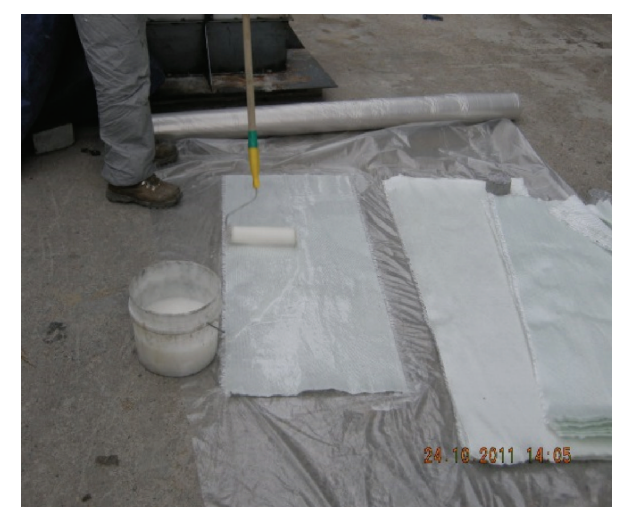

(d)

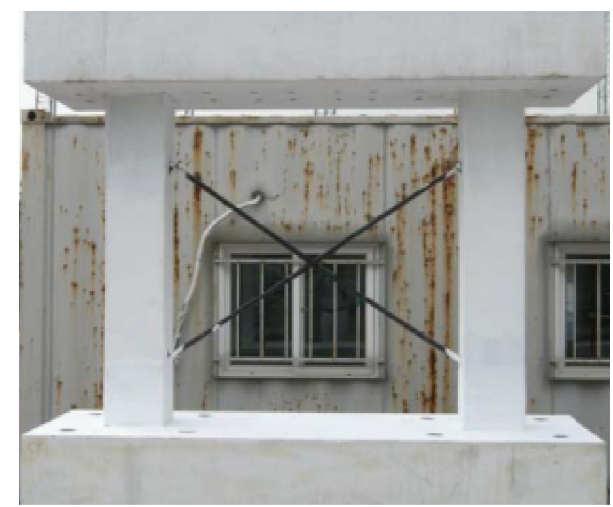

(f)

FIGURE 4: The fabrication procedure. (a) Control specimen with class-V damage, (b) surface treatment and injection of epoxy resin into the crack, (c) drilling of anchoring holes and installation of the CF X-bracing, (d) primer treatment process of the GF sheet, (e) externally bonded GF sheet wrapping, and (f) a specimen strengthened using the hybrid CF X-bracing and GF sheet wrapping system.

was $\mu_{s}=1.25$, which is because the frame of the SF-0 specimen was limited by shear; however, the ductility ratio of the SF-R1 specimen was $\mu_{f}=3.75$ and that of the SF-R2 specimen was $\mu_{f}=2.53$; this represents an increase of a factor of 2-3 compared with the SF-0 control specimen.

We find that both the strength and deformation capacities increased significantly following the application of the hybrid reinforcement system described here, even though the structures were originally damaged until failure (i.e., damage class$\mathrm{V}$, as shown in Figure 3). We also showed that the damaged
RC columns were effectively restored to provide sufficient structural resistance to earthquake loading.

\section{Conclusions}

We have described a novel hybrid seismic retrofitting approach, which combines a noncompression X-bracing system using CF with externally bonded GF sheeting for reinforcement of RC structures that have sustained damage during an earthquake. The GF sheeting was used to improve the 


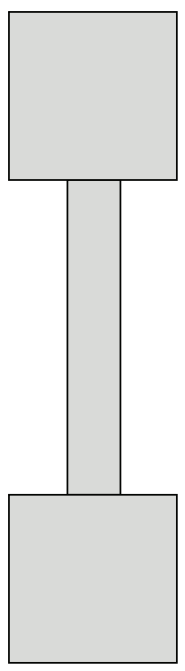

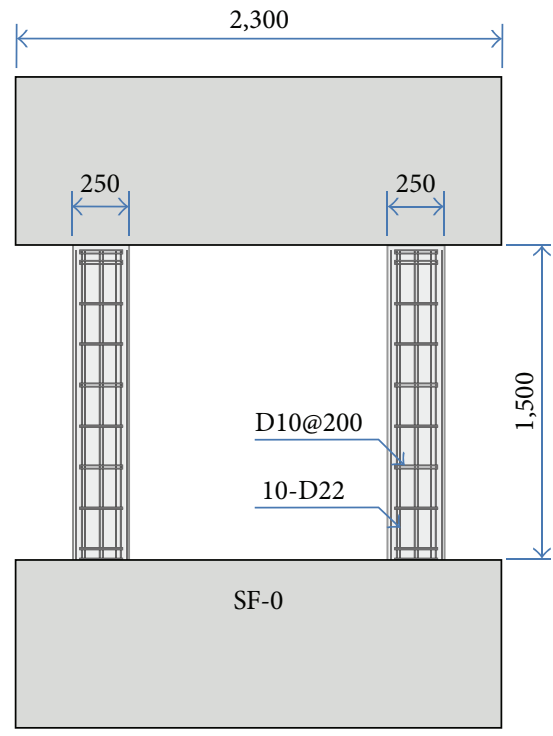

(a)

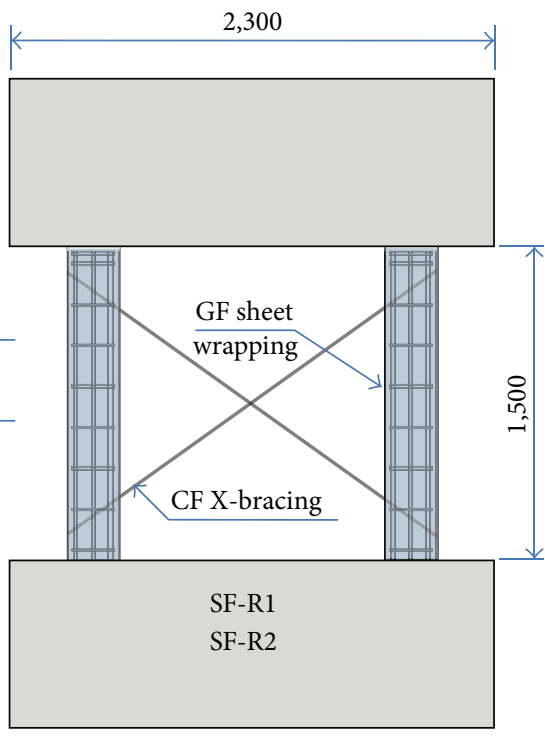

(b)

Figure 5: Details of (a) the SF-0 control specimens and (b) the SF-R reinforced specimens. All dimensions are in $\mathrm{mm}$.

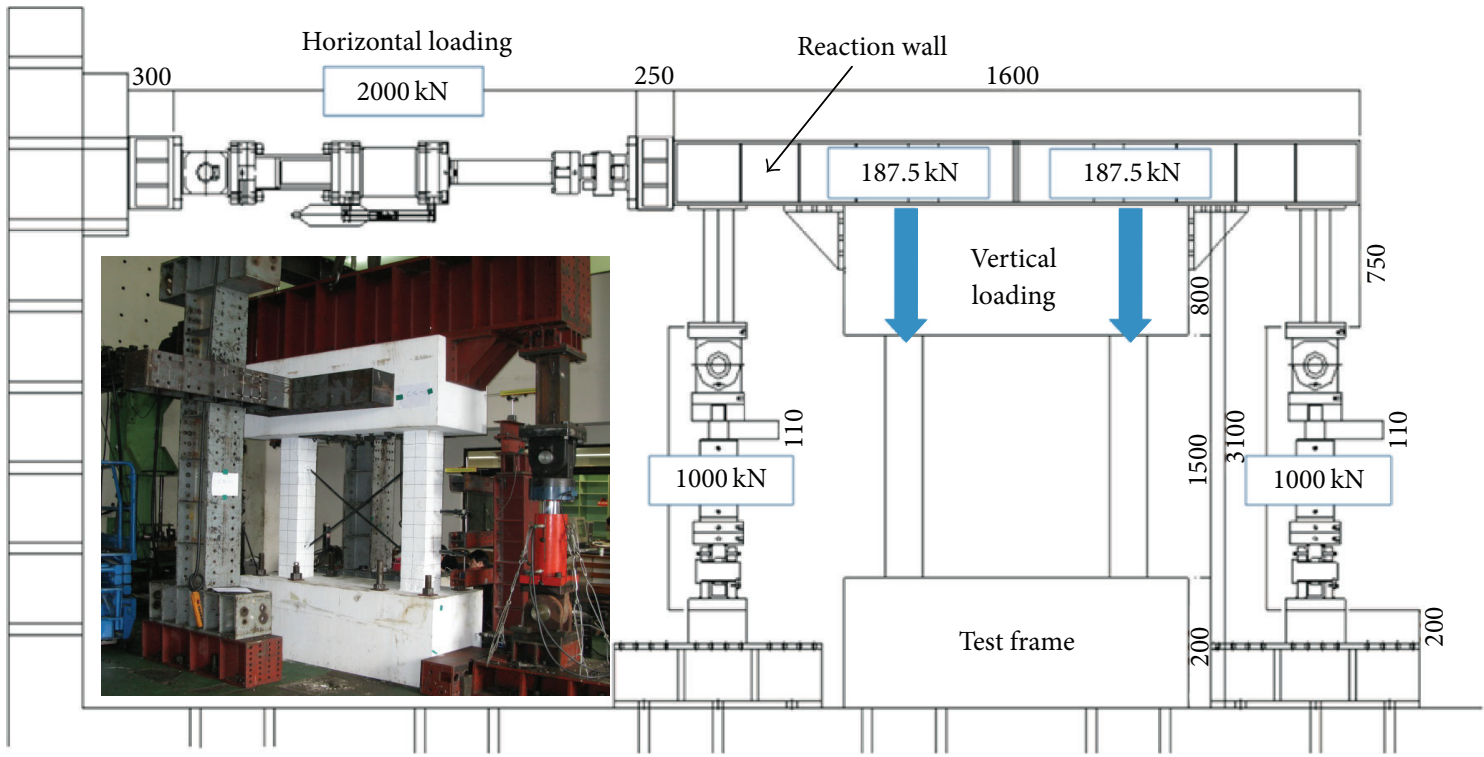

FIGURE 6: The experimental configuration used during the cyclic loading tests.

TABLE 8: Results of mechanical characterizations of the test specimens.

\begin{tabular}{|c|c|c|c|c|c|c|c|}
\hline Specimen & $\begin{array}{c}\text { Load } \\
\text { direction }\end{array}$ & $\begin{array}{l}\text { Yield shear } \\
\text { strength } \\
V_{y}(\mathrm{kN})\end{array}$ & $\begin{array}{c}\text { Maximum shear } \\
\text { strength } \\
V_{\max }(\mathrm{kN})\end{array}$ & $\begin{array}{c}\text { Displacement at } \\
\text { the yield point } \\
\Delta_{y}(\mathrm{~mm})\end{array}$ & $\begin{array}{c}\text { Displacement at } \\
\text { the maximum } \\
\text { point } \\
\Delta_{\max }(\mathrm{mm})\end{array}$ & $\begin{array}{c}\text { Displacement at } \\
\text { the ultimate point } \\
\Delta_{u}(\mathrm{~mm})\end{array}$ & Failure mode \\
\hline \multirow{2}{*}{ SF-0 } & Positive & 200 & 227 & 12.0 & 14.7 & 30.0 & \multirow{2}{*}{ Shear } \\
\hline & Negative & 240 & 278 & 14.0 & 17.5 & 30.0 & \\
\hline \multirow{2}{*}{ SF-R1 } & Positive & 410 & 453 & 35.2 & 44.8 & 114.0 & \multirow{2}{*}{ Flexural } \\
\hline & Negative & 413 & 464 & 32.0 & 44.0 & 120.0 & \\
\hline \multirow{2}{*}{ SF-R2 } & Positive & 459 & 514 & 40.9 & 56.4 & 112.0 & \multirow{2}{*}{ Flexural } \\
\hline & Negative & 515 & 555 & 46.7 & 56.3 & 118.0 & \\
\hline
\end{tabular}


TABLE 9: A summary of the strength and deformation capacities of the test specimens.

\begin{tabular}{|c|c|c|c|c|c|c|c|c|}
\hline \multirow[b]{2}{*}{ Specimen } & \multicolumn{2}{|c|}{ Shear strength $(\mathrm{kN})$} & \multicolumn{3}{|c|}{ Displacement $(\mathrm{mm})$} & \multirow[b]{2}{*}{ Strength ratio* } & \multirow[b]{2}{*}{$\begin{array}{l}\text { Ductility ratio } \\
\left(\mu_{s}^{* *} \text { or } \mu_{f}{ }^{* * *}\right)\end{array}$} & \multirow[b]{2}{*}{ Failure mode } \\
\hline & $\begin{array}{c}\text { Yield } \\
V_{y}\end{array}$ & $\begin{array}{l}\text { Max. } \\
V_{\max }\end{array}$ & $\begin{array}{c}\text { Yield } \\
\Delta_{y}\end{array}$ & $\begin{array}{l}\text { Max. } \\
\Delta_{\max }\end{array}$ & $\begin{array}{c}\text { Ultimate } \\
\qquad \Delta_{u}\end{array}$ & & & \\
\hline SF-0 & 240 & 278 & 14.0 & 17.5 & 30.0 & 1.0 & 1.25 & Shear \\
\hline SF-R1 & 413 & 464 & 32.0 & 44.0 & 120.0 & $1.67(67 \%)$ & 3.75 & Flexure \\
\hline SF-R2 & 515 & 555 & 46.7 & 56.3 & 118.0 & $2.0(100 \%)$ & 2.53 & Flexure \\
\hline
\end{tabular}

*The strength ratio is defined as the maximum load $V_{\max }$ of the SF-R1 or SF-R2 specimens divided by that of the SF- 0 specimen, which indicates strengthening effects in terms of shear strength capacity compared with control SF-0 specimen.

${ }^{* *} \mu_{s}=\Delta_{\max } / \Delta_{y}$ is the ductility ratio for shear failure of specimen SF-0, where $\Delta_{\max }$ is the maximum displacement and $\Delta_{y}$ is the yield displacement. ${ }^{* * *} \mu_{f}=\Delta_{u} / \Delta_{y}$ is the ductility ratio for the flexural failure specimens SF-R1 and SF-R2, where $\Delta_{u}$ is the ultimate displacement and $\Delta_{y}$ is the yield displacement.

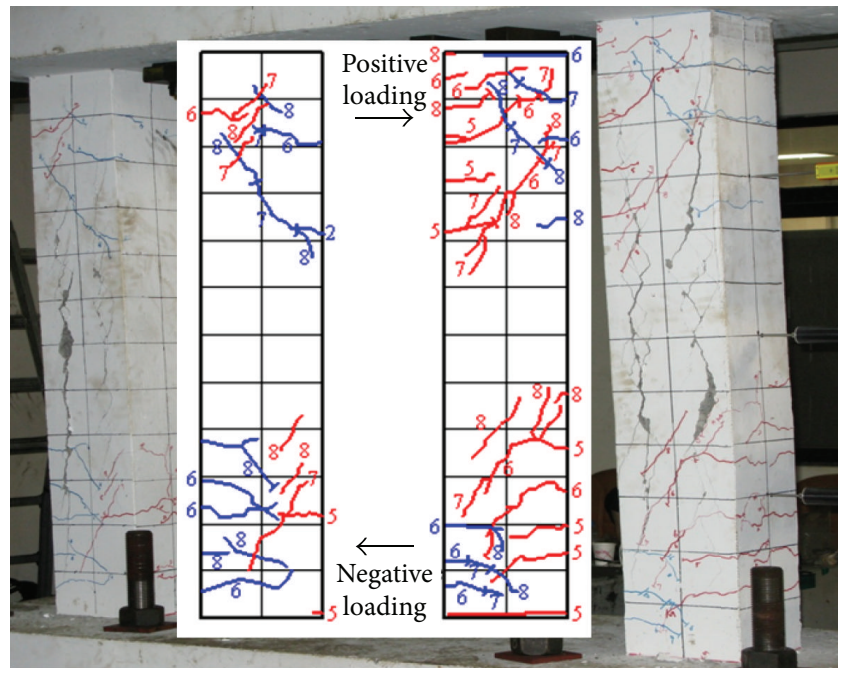

FIGURE 7: Cracks that appeared in the SF-0 specimen during cyclic loading.

ductility of damaged columns. The noncompression CF Xbracing system consisted of CF bracing and anchors rather than conventional steel bracing and bolt connections and was used to increase the lateral strength of the framing system. The restored RC frame strengthened was investigated using cyclic loading tests. We found that the damaged RC frame can be restored following class- $\mathrm{V}$ damage, providing enhanced structural properties compared with the original RC frame. This technique can also be applied to undamaged existing structures to increase both the strength and ductility. The major results of this work are summarized as follows.

(a) The most significant change following the application of the reinforcement system was in the failure mode. Both the SF-R specimens exhibited flexural failure, whereas the control SF-0 specimen exhibited shear failure, which is associated with brittle behavior. The energy absorbing capacity was, therefore, substantially increased compared with the control specimen.

(b) The noncompression CF X-braces, which were used to increase the lateral strength of the framing system, resulted in a considerable reinforcement effect in terms of shear strength compared with the control

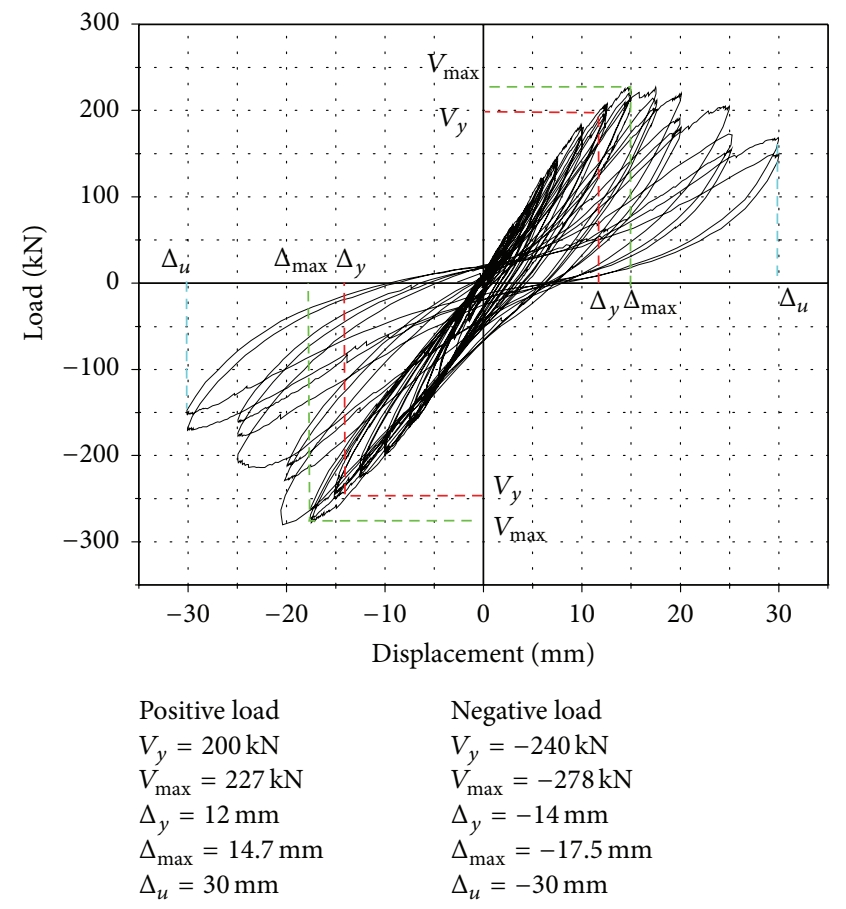

FIGURE 8: Lateral load-displacement curve for the SF-0 specimen.

specimen. The yield load was calculated using Park's method, and the maximum load-carrying capacity increased by $70-100 \%$. The reinforcement effect depends on the bracing material used. It follows that the target reinforcement capacity can be designed via appropriate choice of the type of CF X-bracing.

(c) Considering the change of failure mode to flexural, the specimens SF-R1 and SF-R2 were considerably improved by the externally bonded GF sheet wrapping, representing an increase in the ductility ratio of a factor of 2-3 compared with the SF-0 control specimen. Note that the energy dissipation capacity, which depends on lateral strength and deformation, increased significantly following application of the hybrid CF X-bracing and GF sheet wrapping system.

(d) This hybrid technique for seismic restoration using CF X-bracing and the GFRP can significantly enhance the seismic resistance of the damaged RC columns. 


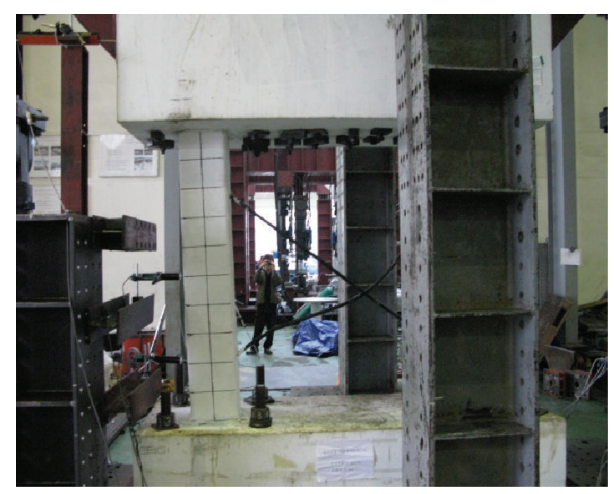

FIGURE 9: The SF-R1 specimen following cyclic loading tests.

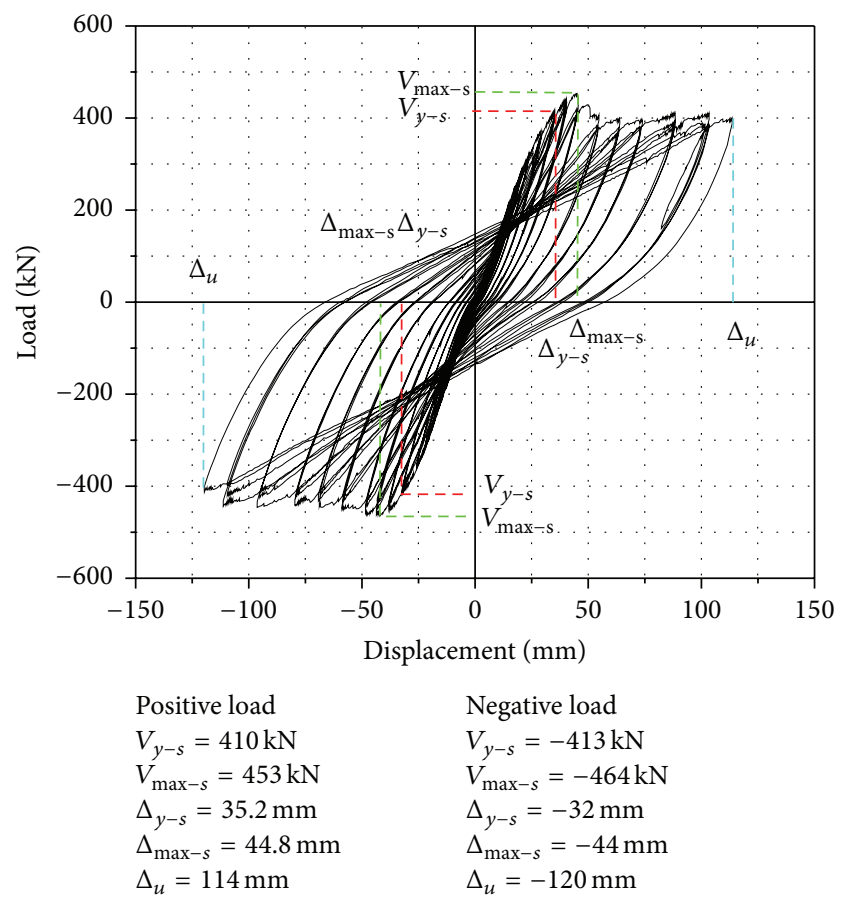

Figure 10: The lateral load-displacement curve for the SF-R1 specimen.

The use of CF X-braces eliminates buckling failure of the bracing, which commonly occurs with conventional steel X-bracing systems. The reinforcement method described here can be applied for seismic restoration of RC structures following damage sustained during an earthquake.

(e) This research, however, was focused on an experimental investigation to study applicability of a new type of hybrid noncompression CF bracing and GF sheet wrapping reinforcement method to restore damaged RC buildings proposed in this research. As a recommendation to the future work, additional theoretical and analytical studies of added GF sheets and CF braces are needed to justify the seismic behavior of the proposed hybrid system, together with seismic strengthening effects of actual RC buildings system

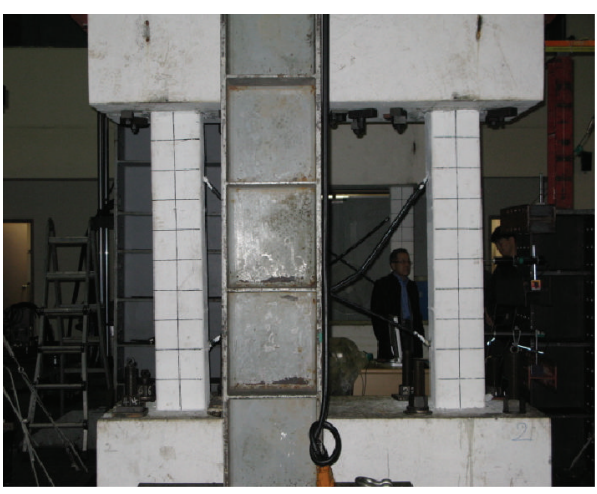

FIGURE 11: The SF-R2 specimen following the cyclic loading tests.

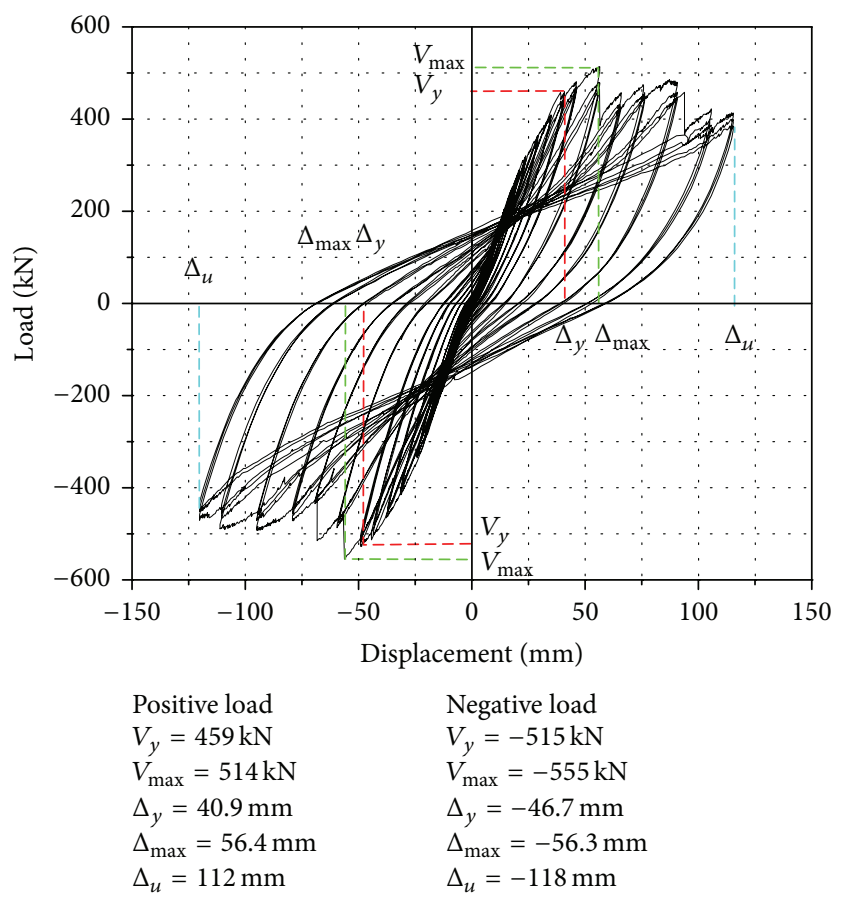

FIGURE 12: Lateral load-displacement curve of the SF-R2 specimen.

before and after strengthening by using the hybrid technique proposed in this study. Furthermore, further work is required to optimize the details of the connections between the bracing and the columns, which is expected to lead to additional improvements in the structural properties of the restored RC frames, and the structural debonding behavior of GF sheet during actual dynamic repeated loads and the development of a suitable application protocol is required for the practical application of our approach.

\section{Acronyms}

RC: Reinforced concrete

FRP: Fiber-reinforced plastic

CF: Carbon fiber

GF: Glass fiber

BRB: Buckling-restrained brace 


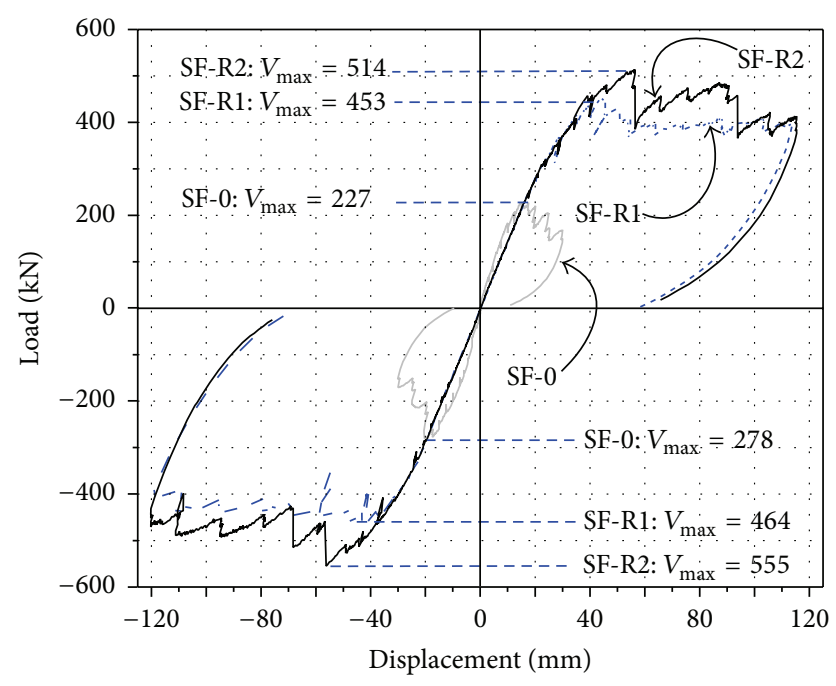

FIGURE 13: Envelop curves for lateral load-displacement relations of all specimens.

BRBF: Buckling-restrained braced frame

SCBF: Special concentrically braced frame

BRBF: Buckling-restrained bracing frame

MBF: Mega-bracing frame

GFRP: Glass fiber-reinforced plastic

UBC: Uniform building code

UTM: Universal testing machine

SF: $\quad$ Shear failure.

\section{Conflict of Interests}

The author declares that there is no conflict of interests regarding the publication of this paper.

\section{Acknowledgments}

This work was supported by the National Research Foundation of Korea Grant (2013R1A1A2009761) funded by the Ministry of Education, Korea, and by a Grant (15CTAPC097490-01) from Technology Advancement Research Program funded by Ministry of Land, Infrastructure and Transport Affairs of Korean Government.

\section{References}

[1] FEMA 310. Handbook for Seismic Evaluation of Buildings-A Prestandard, Federal Emergency Management Agency, 1998.

[2] FEMA 356. Prestandard and Commentary for Seismic Rehabilitation of Buildings, Federal Emergency Management Agency, Washington, DC, USA, 2000.

[3] JBDPA, Standard for Seismic Evaluation of Existing Reinforced Concrete Buildings, Guidelines for Seismic Retrofit of Existing Reinforced Concrete Buildings, and Technical Manual for Seismic Evaluation and Seismic Retrofit of Existing Reinforced Concrete Buildings, Building Disaster Prevention Association, Tokyo, Japan, 2005.
[4] M. Aschheim and E. Black, "Effects of prior earthquake damage on response of simple stiffness-degrading structures," Earthquake Spectra, vol. 15, no. 1, pp. 1-24, 1999.

[5] K. Lee and D. A. Foutch, "Performance evaluation of damaged steel frame buildings subjected to seismic loads," Journal of Structural Engineering, vol. 130, no. 4, pp. 588-599, 2004.

[6] Q. Li and B. R. Ellingwood, "Performance evaluation and damage assessment of steel frame buildings under main shockaftershock earthquake sequences," Earthquake Engineering and Structural Dynamics, vol. 36, no. 3, pp. 405-427, 2007.

[7] M. Maeda, Y. Nakano, and K. S. Lee, "Post-earthquake damage evaluation for R/C buildings based on residual seismic capacity," in Proceedings of the 13th World Conference on Earthquake Engineering, Vancouver, Canada, August 2004.

[8] K. S. Lee, "Experimental study on sprayed frp system for strengthening reinforced concrete beams," Journal of Advanced Concrete Technology, vol. 10, no. 6, pp. 219-230, 2012.

[9] M. R. Maheri, R. Kousari, and M. Razazan, "Pushover tests on steel X-braced and knee-braced RC frames," Engineering Structures, vol. 25, no. 13, pp. 1697-1705, 2003.

[10] K. G. Viswanath, K. B. Prakash, and A. Desai, "Seismic analysis of steel braced reinforced concrete frames," International Journal of Civil and Structural Engineering, vol. 1, no. 1, pp. 114-122, 2012.

[11] F. Nateghi-Alahi, "Seismic strengthening of eight-storey RC apartment building using steel braces," Engineering Structures, vol. 17, no. 6, pp. 455-461, 1995.

[12] E. A. Jones and J. O. Jirsa, "Seismic strengthening of a reinforced concrete frame using structural steel bracing," Report on a Research Project, National Science Foundation, 1986.

[13] S. J. Hwang, T. C. Chiou, F. P. Hsiao, Y. J. Chiou, and S. M. Alcocer, "Field test of RC school building retrofitted by posttensioned rods," in Proceedings of the 14th World Conference on Earthquake Engineering, Beijing, China, 2008.

[14] M. R. Maheri and A. Sahebi, "Experimental investigation on the use of steel bracing in reinforced concrete frames," in Proceedings of the 2nd International Conference on Seismic and Earthquake Engineering, pp. 775-784, Tehran, Iran, 1995.

[15] M. R. Maheri and A. Sahebi, "Use of steel bracing in reinforced concrete frames," Engineering Structures, vol. 19, no. 12, pp. 10181024, 1997.

[16] H. Abou-Elfath and A. Ghobarah, "Behaviour of reinforced concrete frames rehabilitated with concentric steel bracing," Canadian Journal of Civil Engineering, vol. 27, no. 3, pp. 433444, 2000.

[17] A. Ghobarah and H. Abou-Elfath, "Rehabilitation of a reinforced concrete frame using eccentric steel bracing," Engineering Structures, vol. 23, no. 7, pp. 745-755, 2001.

[18] H. Y. Chang and C. K. Chiu, "Performance assessment of buckling restrained braces," Procedia Engineering, vol. 14, pp. 2187-2195, 2011.

[19] Q. Xie, "State of the art of buckling-restrained braces in Asia," Journal of Constructional Steel Research, vol. 61, no. 6, pp. 727748, 2005.

[20] O. C. Celik and M. Bruneau, "Seismic behavior of bidirectionalresistant ductile end diaphragms with buckling restrained braces in straight steel bridges," Engineering Structures, vol. 31, no. 2, pp. 380-393, 2009.

[21] G. Palazzo, F. López-Almansa, X. Cahís, and F. Crisafulli, "A low-tech dissipative buckling restrained brace. Design, analysis, production and testing," Engineering Structures, vol. 31, no. 9, pp. 2152-2161, 2009. 
[22] C. Ariyaratana and L. A. Fahnestock, "Evaluation of bucklingrestrained braced frame seismic performance considering reserve strength," Engineering Structures, vol. 33, no. 1, pp. 7789, 2011.

[23] L. di Sarno and A. S. Elnashai, "Bracing systems for seismic retrofitting of steel frames," Journal of Constructional Steel Research, vol. 65, no. 2, pp. 452-465, 2009.

[24] H. Tamai and T. Takamatsu, "Cyclic loading tests on a non-compression brace considering performance-based seismic design," Journal of Constructional Steel Research, vol. 61, no. 9, pp. 13011317, 2005.

[25] S. Witt, "Development in fiber roving anchors for use with externally bonded fiber reinforced polymers," in Proceedings of the 8th International Symposium on Fiber Reinforced Polymer Reinforcement for Concrete Structures, Paper no. 15-11, Patras, Greece, July 2007.

[26] S. J. Kim and S. T. Smith, "Behaviour of handmade FRP anchors under tensile load in uncracked concrete," Advances in Structural Engineering, vol. 12, no. 6, 2009.

[27] T. Ozbakkaloglu and M. Saatcioglu, "Tensile behavior of FRP anchors in concrete," Journal of Composites for Construction, vol. 13, no. 2, pp. 82-92, 2009.

[28] S. T. Smith and S. J. Kim, "Shear strength and behavior of FRP spike anchors in FRP-to-concrete joint assemblies," in Proceedings of the 5th International Conference on Advanced Composite Materials in Bridges and Structures (ACMBS-V'08), Winnipeg, Canada, September 2008.

[29] J. Neuner and R. Falabella, "Composite anchor system-flatwise tensile and shear testing," Internal Report of Hexcel Corporation, Hexcel, Stamford, Conn, USA, 1999.

[30] Conclinic, Catalogue of CAF-GL1000, Conclinic, Seoul, Republic of Korea, 2010.

[31] Uniform Building Code, "Structural engineering design provision," in Proceedings of the International Conference of Building Officials, Whittier, Calif, USA, 1997.

[32] K. S. Lee, "Seismic capacity requirements for low-rise reinforced concrete buildings controlled by both shear and flexure," Journal of Advanced Concrete Technology, vol. 8, no. 1, pp. 75-91, 2010.

[33] R. Park, "Ductility evaluation from laboratory and analytical testing," in Proceedings of the 9th World Conference on Earthquake Engineering, vol. 8, pp. 605-616, Tokyo, Japan, 1988. 

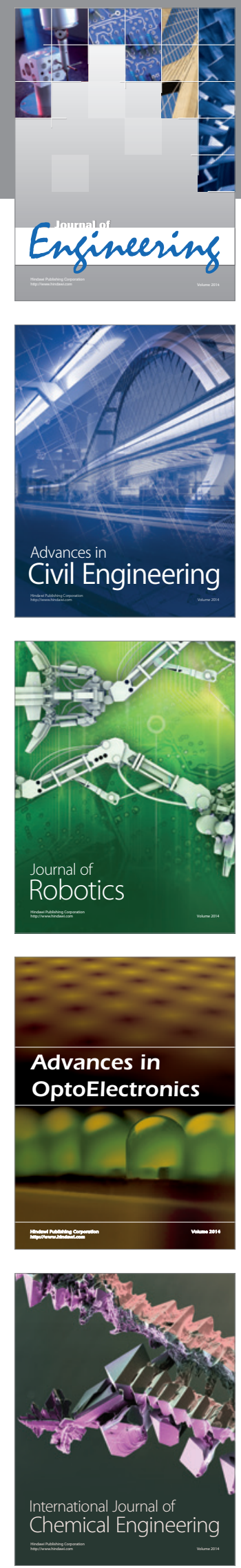

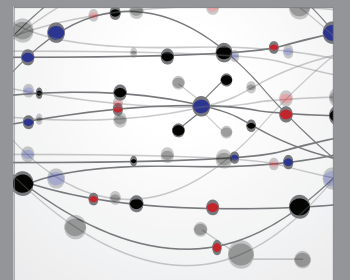

The Scientific World Journal
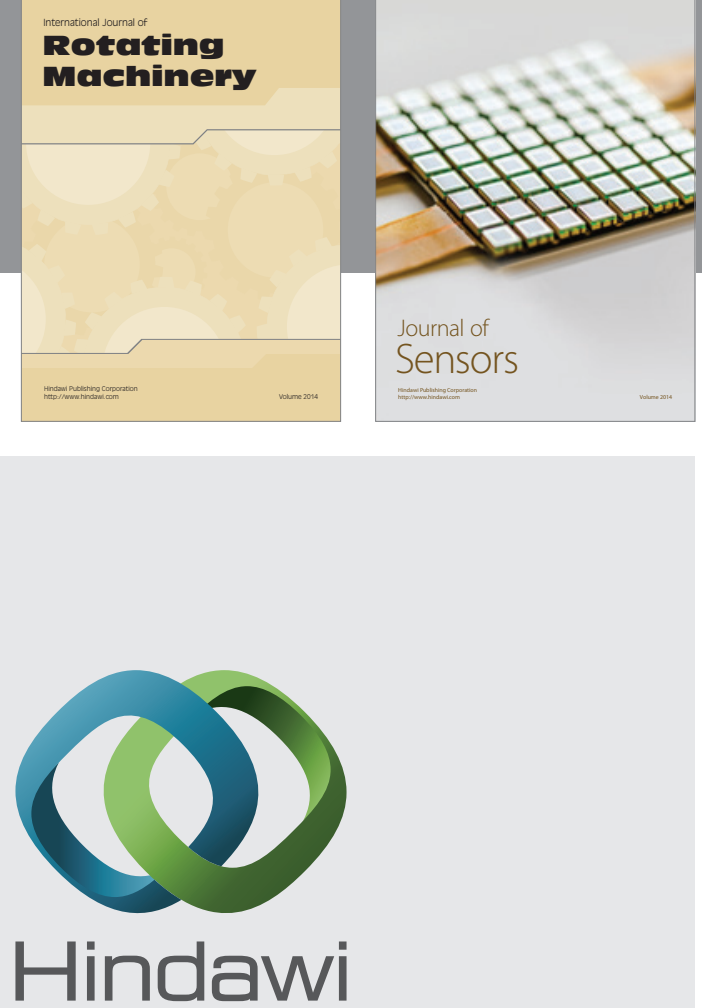

Submit your manuscripts at http://www.hindawi.com
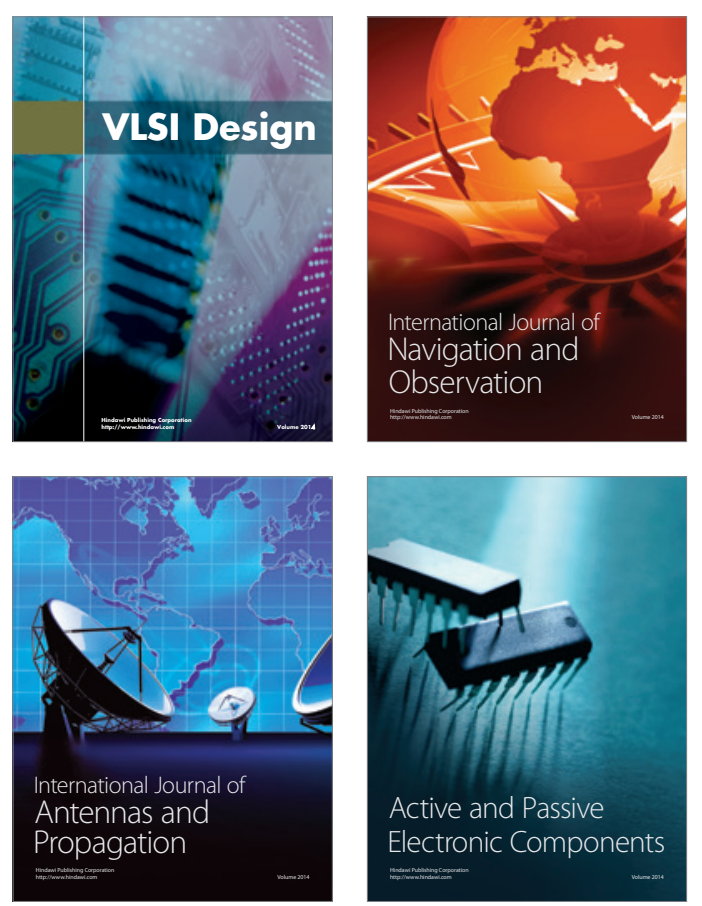
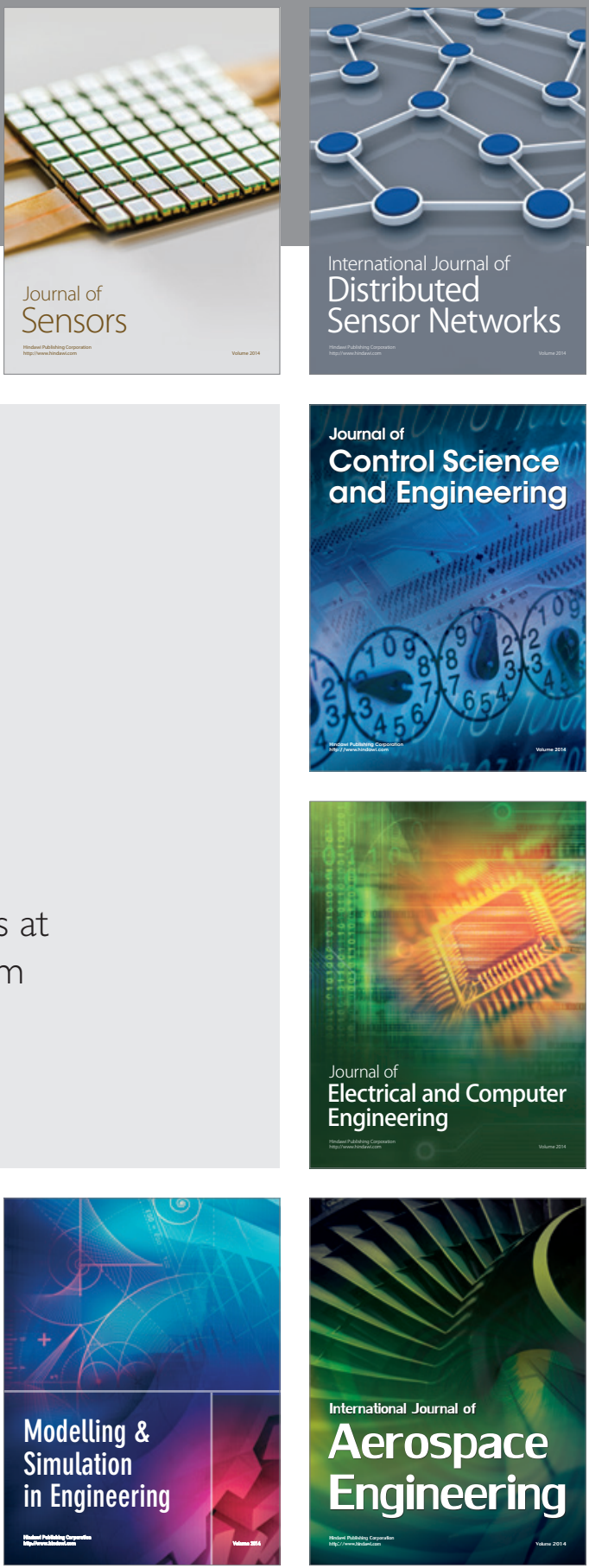

Journal of

Control Science

and Engineering
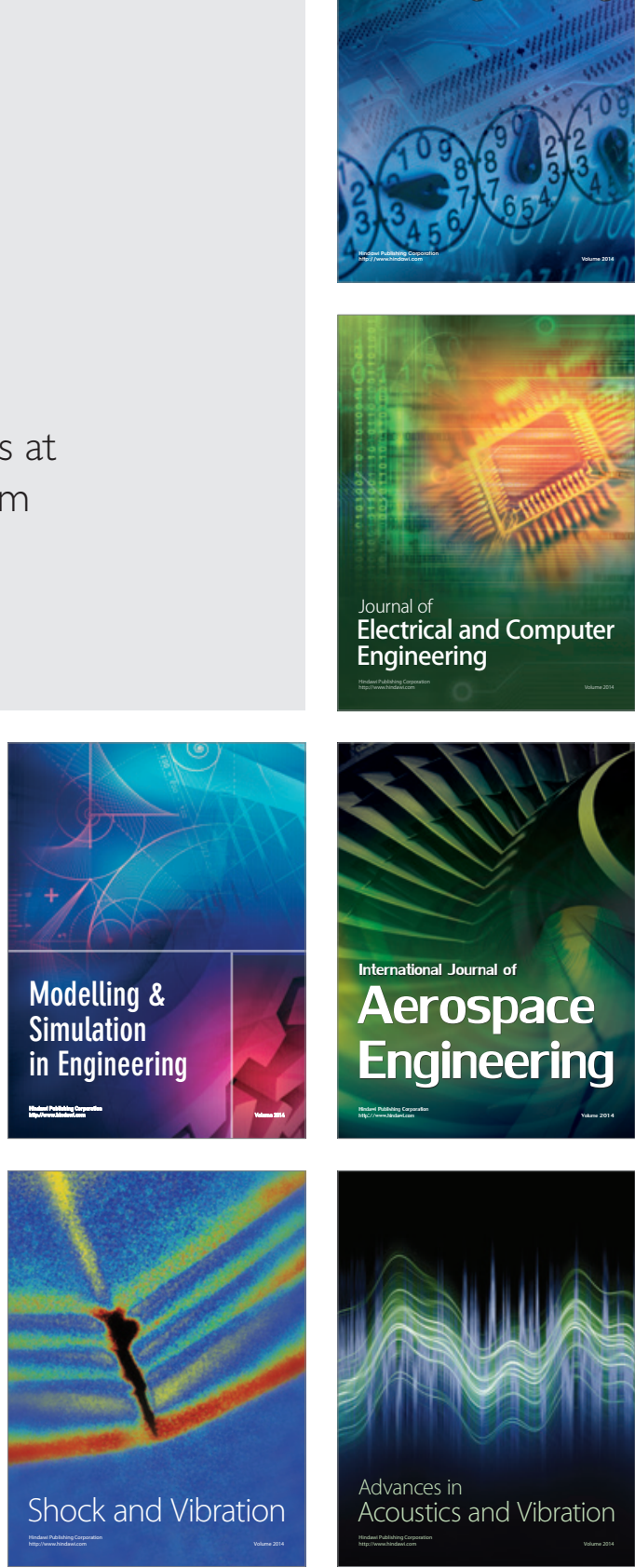